\title{
IDENTIFIKASI BAKTERI DAN FAKTOR RISIKO KEJADIAN PRESSURE ULCER DI RSUD AWS SAMARINDA
}

\author{
Diah Setiani ${ }^{11}$, Indah Nur Imamah') \\ 1),2)Prodi D-III Keperawatan, Poltekkes Kemenkes Kaltim \\ Email : diah.dee.oc@gmail.com
}

\begin{abstract}
The pressure ulcer interferes with the patient's recovery process, followed by complications with pain and infection thus add to the length of treatment. Pressure ulcers pose a threat in health services because the incident is increasing every day (Spilsbury, et al, 2010). Purpose of this study to know the descriptio of bacteria on pressure ulcer and pressure ulcer $f$ actor in AW. Sjahranie regional hospital in Samarinda.

Research method used descriptive reasearch. Where the population are all patients who has pressure ulcer. Sampling technique used accidental sampling method held in AW. Sjahranie regional hospital in Samarinda on October 2017 covering HCU room, , stroke center, anggrek, angsoka and flamboyan as many as 11 people. The variable measured in this study is identification of bacteria, risk factors (sensory perception, moisture, activity, mobilization, nutrition, friction and tears). The analysis used is univariate analysis, namely in the form of data frequency distribution and percentage, covering the characteristics of respondents and risk factor braden scale. This research has received the approval of ethical conduct from the health research ethics commission in AW. Sjahranie regional hospital in Samarinda number 030/KEPK-AWS/XI/2017.

The results of the research conducted on 11 respondents found: The highest type of gram negative germs found in the pressure ulcer $(81 \%)$ Acinetobacter $\mathrm{sp}$ is the most dominant microorganism that has pressure wounds, $63.6 \%$ of respondents have normal sensory perception, $63,6 \%$ of the respondent's humidity is always wet, $81.8 \%$ of the patient's pressure ulcer activity is bedrest, $63.6 \%$ of the respondent's mobility is total immobilization, $54.5 \%$ of the respondent's nutritional condition is sufficient, as much as $72.7 \%$ friction and torn repondents have a problem. Service providers are expected to be able to assess the incidence of pressure ulcers and control infection in patients with total / bedrest dependence so that the incidence can be reduced.
\end{abstract}

Keywords : Bacteria, risk factor pressure ulcer.

\begin{abstract}
Abstrak
Adanya pressure ulcer mengganggu proses pemulihan pasien, diikuti komplikasi dengan nyeri dan infeksi sehingga menambah panjang lama perawatan. Pressure ulcer menimbulkan sebuah ancaman dalam pelayanan kesehatan karena insidennya semakin hari semakin meningkat (Spilsbury, et al, 2010). Tujuan penelitian ini, mengetahui gambaran bakteri pada pressure ulcer dan faktor kejadian pressure ulcer di RSUD AWS Samarinda.
\end{abstract}


Metode penelitian yang digunakan adalah penelitian deskriptif. Dimana populasi adalah semua pasien yang mengalami pressure ulcer. Teknik pengambilan sampel (sampling) menggunakan metode accidental sampling dilaksanakan di RSUD AWS Samarinda pada bulan Oktober Tahun 2017 meliputi ruang HCU, stroke center, anggrek, angsoka dan flamboyan sebanyak 11 orang. Variable dalam yang diukur penelitian ini adalah identifikasi bakteri, faktor risiko (persepsi sensori, kelembaban, aktifitas, mobilisasi, nutrisi, gesekan dan robekan). Analisis yang digunakan adalah analisis univariat yaitu dalam bentuk data yang disajikan dalam bentuk tabel distribusi frekuensi dan persentase, meliputi karakteristik responden dan faktor risiko skala braden. Penelitian ini telah mendapatkan persetujuan kelakayan etik dari komisi etik penelitian kesehatan RSUD A. Wahab Sjahranie Samarinda dengan nomor 030/KEPK-AWS/XI/2017 .

Hasil penelitian yang dilakukan pada 11 orang responden didapatkan: Jenis kuman gram negative paling banyak terdapat di pressure ulcer sebesar $(81 \%)$ Acinetobacter sp adalah mikroorganisme yang paling dominan terdapat diluka pressure, sebanyak $63,6 \%$ responden memiliki persepsi dan sensori normal, sebanyak 63,6 \% kelembaban responden adalah selalu basah, sebanyak $81,8 \%$ kegiatan pasien pressure ulcer adalah bedrest, sebanyak $63,6 \%$ mobilitas responden adalah imobilisasi total, sebanyak $54,5 \%$ kondisi nutrisi responden adalah cukup, sebanyak $72,7 \%$ gesekan dan robekan reponden memiliki masalah. Bagi para pemberi pelayanan diharapkan dapat melakukan pengkajian faktor kejadian pressure ulcer serta dapat mengendalikan infeksi pada pasien dengan ketergantungan total/ bedrest sehingga angka kejadian dapat berkurang.

Kata kunci : Bakteri, faktor risiko Pressure Ulcer.

\section{PENDAHULUAN}

Pressure ulcer (sinonimnya pressure sore, pressure area, bedsore, decubitus, ischemia ulcer) merupakan masalah yang sangat serius terutama bagi pasien yang menjalani perawatan lama lebih dari 48 jam dengan keterbatasan aktifitas (Scheel-Sailer, Wyss, Boldt, Post, \& Lay, 2013). Hasil studi di Amerika menunjukkan bahwa insiden kejadian pressure ulcer bervariasi antara 5,2 \% sampai dengan $35 \%$ pada pasien yang dirawat di ruang rawat inap, sedangkan di Spanyol menunjukkan peningkatan insiden yaitu $24,20 \%$ pada tahun 2009 (Carmen, 2013). Di Indonesia, kejadian pressure ulcer cukup tinggi yaitu 33,3\% (Suriadi, 2008). Di Rumah Sakit Umum Daerah Abdul Wahab Sjahranie (RSUD AWS) Samarinda sebagai rumah sakit tipe $A$ sekaligus rumah sakit terbesar di Kalimantan Timur terdapat insiden kejadian pressure ulcer 15,8 \%o mengalami dalam periode bulan januari s/d agustus pada tahun 2017. (Data PPI RSUD AWS, 2017).

Adanya pressure ulcer mengganggu proses pemulihan pasien, mungkin juga diikuti komplikasi dengan nyeri dan infeksi sehingga menambah panjang lama perawatan. Pressure ulcer menimbulkan sebuah ancaman dalam pelayanan kesehatan karena insidennya semakin hari semakin meningkat (Spilsbury, et al, 2010). Multipleand life threatening medical complications dapat terjadi akibat dari timbulnya dekubitus selama pasien dirawat di rumah sakit. Akibat 
dari hal tersebut diatas, timbulnya pressure ulcer juga dapat meningkatkan durasi lamanya tinggal di rumah sakit atau LOS (length of stay) sehingga hal ini akan meningkatkan beban terutama biaya rawat inap akan meningkat seiring dengan lamanya waktu tinggal di rumah sakit (Widodo, 2007). Secara finansial, penanganan pressure ulcer meningkatkan biaya perawatan. Dutch Study Found mencatat biaya perawatan untuk pressure ulcer tertinggi ketiga setelah biaya perawatan kanker dan penyakit kardiovaskuler. Amerika Serikat mengeluarkan 11 milyar US setiap tahun untuk menangani pressure ulcer (Reddy,dkk.,2008).

Banyak faktor yang ikut berperan dalam terjadinya pressure ulcer seperti shear (geseran), friction (gesekan), kelembaban yang berlebihan, dan mungkin juga infeksi (Gitarja, 2014). Pressure ulcer dapat digolongkan menjadi luka kronis. Pressure ulcer merupakan luka terbuka kronis yang sering dijumpai di berbagai rumah sakit. Pressure ulcer sering terjadi akibat penekanan pada kulit yang disertai dengan imobilisasi pasien. Selain itu akibat pengaruh kulit yang terlalu kering ataupun basah sehingga memudahkan terjadinya kolonisasi bakteri (Gibb et al., 2007). Pada luka kronis terdapat flora mikrobial yang beragam. Awalnya luka dikolonisasi dengan mikroorganisme komensal di kulit, tetapi pola kolonisasi berubah seiring waktu. Mikroorganisme Gram positif awalnya menginvasi luka, kemudian diikuti oleh mikroorganisme Gram negatif dan spesies anaerob. Kuman yang sering dijumpai pada pressure ulcer adalah Proteus mirabilis group D streptococci, Escheria coli, Staphylococcus species, Pseudomonas species, dan Corynebacterium. Pasien dengan bakteremia lebih sering terinfeksi dengan Bactiroides sp. Pada pressure ulcer ditandai dengan bau yang tidak sedap, leukositosis, demam, hipotensi dan peningkatan denyut jantung dan perubahan status mental.

Dalam upaya pencegahan pressure ulcer yang pertama kali dilakukan yaitu pengkajian risiko dan faktor risiko sesegera mungkin (dalam waktu maksimal 8 jam setelah masuk) untuk mengidentifikasi pasien yang berisiko terkena pressure ulcer (NPUAP, Prevention and Treatment of Pressure ulcers: Quick Reference Guide, 2014), serta melakukan identifikasi bakteri yang terdapat pada pressure ulcer. Menurut AHCPR (2008) Braden's Scale merupakan suatu alat yang dirancang untuk memudahkan pengkajian faktor risiko terjadinya pressure ulcer pada pasien yang dikembangkan oleh Barbara J. Braden dan Nancy Bergstrom (1984). Braden's Scale terdiri atas 6 sub skala yang mengevaluasi persepsi sensori, kelembaban, tingkat aktifitas, mobilitas, status nutrisi, gesekan dan robekan (Ayello, 2007). Braden's Scale telah diuji penggunaannya pada setting perawatan medikal bedah, perawatan intensif dan nursing home. Braden's Scale memiliki overprediction tinggi dan underprediction rendah (Brown, S.J., 2004).

Penelitian ini bertujuan, mengetahui gambaran bakteri pada pressure ulcer dan faktor kejadian 
pressure ulcer di RSUD AWS Samarinda.

\section{METODE PENELITIAN}

Metode penelitian yang digunakan adalah penelitian deskriptif. Populasi pada penelitian ini adalah semua pasien yang mengalami pressure ulcer di RSUD AWS. Teknik pengambilan sampel (sampling) pada penelitian ini menggunakan metode accidental sampling dilaksanakan di RSUD AWS Samarinda pada bulan Oktober Tahun 2017 meliputi ruang HCU, stroke center, anggrek, angsoka dan flamboyan sebanyak 11 orang.

Variable dalam yang diukur penelitian ini adalah identifikasi bakteri, faktor risiko (persepsi sensori, kelembaban, aktifitas, mobilisasi, nutrisi, gesekan dan robekan).

Alat pengumpul data yang digunakan dalam mengidentifikasi bakteri antara lain plastik gula, autoclave, inkubator, tabung reaksi steril, tabung durham steril, erlenmeyer, cawan petri, ose, lampu spirtus, kaca objek, rak pewarnaan, pipet ukur, aluminium foil, dan mikroskop. Tabel data, bahan sampel pasien dengan pressure ulcer. Media yang digunakan Brain Heart Infution (BHI), Mac Conkey (MC), Salmonella Shigella Agar (SSA), dan media uji biokimia (methyl red, voges proskauer, simmon citrate, sulfur indol motil, triple sugar iron agar) media gula-gula (glukosa, laktosa, manitol, maltosa, sukrosa), cat Gram (gentiant violet, lugol, alkohol 96\%, safranin), Nacl $0,9 \%$ dan Aquades. Dan reagensia yang digunakan methyl red, larutan kovac, $\mathrm{KOH} 40 \%$ dan a-naftol $5 \%$. Kemudian alat pengumpul data yang digunakan dalam mengidentifikasi faktor risiko adalah kuesioner, instrument braden scale.

Analisis yang digunakan adalah analisis univariat yaitu dalam bentuk data yang disajikan dalam bentuk tabel distribusi frekuensi dan persentase, meliputi karakteristik responden : umur, jenis kelamin, riwayat merokok, IMT, dan lama rawat, diagnosa dan faktor persespsi sensori, kelembaban, aktifitas, mobilitas, nutrisi, serta gesekan dan robekan.

Penelitian ini telah mendapatkan persetujuan kelakayan etik dari komisi etik penelitian kesehatan RSUD A. Wahab Sjahranie Samarinda dengan nomor 030/KEPKAWS/XI/2017 .

\section{HASIL PENELITIAN}

Penelitian ini dilakukan mulai tanggal 9 sampai dengan 27 Oktober 2017 di Ruang Anggrek, Flamboyan, angsoka, stroke center dan $\mathrm{HCU}$ RSUD AWS Samarinda, dengan jumlah sampel 11 orang. Responden yang diambil adalah yang memiliki luka tekan. Pengambilan sampel diawali dengan membersihkan luka dengan menggunakan air steril kemudian dilakukan pengukuran faktor risiko dengan menggunakan skala braden. 
Tabel 1 Distribusi Frekuensi Karakteristik Responden Di RSUD AWS

\begin{tabular}{lcr}
\hline \multicolumn{1}{c}{ Karakteristik } & Frekuensi & Presentas \\
\hline Usia : & & \\
15-49 tahun & 4 & 36,4 \\
50-64 tahun & 4 & 36,4 \\
$>65$ tahun & 3 & 27,3
\end{tabular}

$\begin{array}{lll}\text { Jenis kelamin: } & & \\ \text { Laki-laki } & 7 & 63,6 \\ \text { Perempuan } & 4 & 36,4\end{array}$

\section{Riwayat merokok:}

Ya $\quad 5 \quad 45,5$

Tidak $\quad 6 \quad 54,5$

\begin{tabular}{lcc}
\hline IMT : & & \\
Kurus & 1 & 9,1 \\
Ideal & 8 & 72,7 \\
Obesitas & 2 & 18,2
\end{tabular}

\section{Lama rawat :}

$\begin{array}{llc}<7 \text { hari } & 6 & 54,5 \\ >7 \text { hari } & 5 & 45,5 \\ \text { Diagnosa medis } & & \\ \text { Stroke non hemoragic } & 4 & 36,4 \\ \text { Diabetes mielitus } & 3 & 27,3 \\ \text { Cronic kidney desease } & 1 & 9,1 \\ \text { Post bedah } & 1 & 9,1 \\ \text { Penyakit infeksi } & 2 & 18,2\end{array}$

Berdasarkan tabel 1 menunjukkan bahwa hasil analisis univariat, sebagian besar responden: $4(36,4 \%)$ berusia 15-49 tahun dan 4 (36,4 \%) 50-64 tahun, 7 $(63,6 \%)$ berjenis kelamin laki-laki, $6(54,5 \%)$ tidak memiliki riwayat merokok, $8(72,7$ $\%)$ memiliki IMT ideal, 6 (54,5\%) memiliki masa lama rawat $<7$ hari, $4(36,6 \%)$ berdiagnosa medis stroke non hemoragic.

Tabel 2 Gambaran Kuman Pada Luka Dekubitus

\begin{tabular}{ccc}
\hline Jenis Kuman & Jumlah & Prosentase (\%) \\
\hline Gram negative & 9 & 81 \\
Gram positif & 2 & 18 \\
\hline Total & 11 & 100
\end{tabular}

Dari table 2 dapat dilihat bahwa jenis kuman gram negative paling banyak terdapat di pressure ulcer sebesar $(81 \%)$ 
Tabel 3 Gambaran Jenis Mikroorganisme Pada Luka Dekubitus

\begin{tabular}{ccc}
\hline Jenis mikroorgnisme & Jumlah responden & Prosentase \\
\hline Proteus mirabilis & 1 & $9 \%$ \\
Staphylococcus sp & 2 & $18 \%$ \\
Acinetobacter sp & 4 & $36 \%$ \\
Serratia sp & 1 & $9 \%$ \\
Enterobacter sp & 2 & $18 \%$ \\
Pseudomonas sp & 1 & $9 \%$ \\
\hline \multicolumn{6}{c}{ Jumlah } & 11 & $100 \%$ \\
\hline Dari tabel 3 di atas, diketahui bahwa Acinetobacter sp adalah
\end{tabular}

mikroorganisme yang paling dominan terdapat diluka pressure ulcer sebesar $36 \%$.

Tabel 4 Faktor Persepsi Sensori

\begin{tabular}{lcc}
\hline & Frekuensi & Presentasi $(\%)$ \\
\hline Terbatas total & 3 & 27,3 \\
Sangat terbatas & 1 & 9,1 \\
Normal & 7 & 63,6 \\
\hline Total & 11 & 100
\end{tabular}

Berdasarkan tabel 4 menunjukkan bahwa hasil analisis univariat, sebagian besar responden 7 (63,6 \%) faktor persepsi dan sensorinya adalah normal.

Tabel 5 Faktor kelembaban

\begin{tabular}{lcc}
\hline & Frekuensi & Presentasi (\%) \\
\hline Selalu basah & 7 & 63,6 \\
Sangat lembab & 2 & 18,2 \\
Jarang lembab & 2 & 18,2 \\
\hline Total & 11 & 100
\end{tabular}

Berdasarkan tabel 5 menunjukkan bahwa hasil analisis univariat, sebagian besar responden 7 (63,6 \%) faktor kelembaban selalu basah.

Tabel 6 Faktor aktifitas

\begin{tabular}{lcc}
\hline & Frekuensi & Presentasi (\%) \\
\hline Bed rest & 9 & 81,8 \\
Mampu berjalan kadang-kadang & 2 & 18,2 \\
\hline Total & 11 & 100
\end{tabular}

Berdasarkan tabel 6 menunjukkan bahwa hasil analisis univariat, sebagian besar responden $9(81,8 \%)$ faktor aktifitas adalah bedrest. 
Tabel 7 Faktor mobilitas

\begin{tabular}{lcc}
\hline & Frekuensi & Presentasi (\%) \\
\hline Imobilisasi total & 7 & 63,6 \\
Sangat terbatas & 2 & 18,2 \\
Terbatas ringan & 1 & 9,1 \\
Tidak terbatas & 1 & 9,1 \\
\hline Total & 11 & 100
\end{tabular}

Berdasarkan tabel 7 menunjukkan bahwa hasil analisis univariat, sebagian besar responden $7(63,6 \%)$ faktor mobilitas adalah imobilisasi total.

Tabel 8 Faktor nutrisi

\begin{tabular}{lcc}
\hline & Frekuensi & Presentasi (\%) \\
\hline Sangat buruk & 2 & 18,2 \\
Mungkin buruk & 1 & 9,1 \\
Cukup & 6 & 54,5 \\
Baik & 2 & 18,2 \\
\hline Total & 11 & 100
\end{tabular}

Berdasarkan tabel 4.8 menunjukkan bahwa hasil analisis univariat, sebagian besar responden 6 (54,5\%) faktor nutrisinya cukup.

Tabel 9 Faktor gesekan dan robekan

\begin{tabular}{lcc}
\hline & Frekuensi & Presentasi (\%) \\
\hline Masalah & 8 & 72,7 \\
Berpotensi masalah & 2 & 18,2 \\
Tidak ada masalah & 1 & 9,1 \\
\hline Total & 11 & 100
\end{tabular}

Berdasarkan tabel 4.9 menunjukkan bahwa hasil analisis univariat, sebagian besar responden $8(72,7 \%)$ faktor gesekan dan robekan memiliki masalah.

\section{PEMBAHASAN}

Hasil penelitian ini menyatakan bahwa bakteri yang terdapat di luka tekan berbeda beda jenisnya. Dari 11 responden, bakteri yang paling banyak terdapat di luka tekan adalah gram negative sebesar (81\%) dengan mikroorganisme yang paling dominan adalah Acinetobacter sp $36 \%$. Hasil penelitian ini sejalan dengan penelitian mona, selvi (2017) yang menyebutkan jenis mikroorganisme yang terbanyak pada ulkus dekubitus di instalasi rawat inap RSUP H.Adam Malik Medan adalah Gram negatif yaitu pada 26 subjek $(89,8 \%)$ dan spesies mikroorganisme yang terbanyak adalah Acinetobacter baumannii yang ditemukan pada 20 subjek (69\%).

Mikroorganisme yang paling sering terlibat dalam kolonisasi ulkus dekubitus adalah kokus Gram positif seperti Staphylococcus aureus, Enterobacteriaceae, dan basil Gram negatif seperti Pseudomonas aeruginosa, Proteus mirabilis dan Acinetobacter baumannii. Pada luka kronis terdapat flora mikrobial yang beragam. 
Bakteri genus Acinetobacter adalah bakteri aerob, kokobasil Gram negatif, dan banyak terdapat pada tanah dan air. Acinetobacter dapat juga diisolasi dari kulit, mukosa atau cairan tubuh. Bakteri tersebut tumbuh pada banyak media perbenihan yang biasanya digunakan untuk mengisolasi mikroba pathogen, sehingga seringkali dikelirukan dengan bakteri yang patogen. Namun demikian Acinetobacter bersifat komensal dan dapat menyebabkan infeksi nosokomial yang sukar diobati karena resisten terhadap banyak golongan obat antimikroba (Dzen, 2003).

Acinetobacter baumannii merupakan bakteri gram negatif yang bersifat aerob dengan karakteristik yang cepat resisten terhadap antibiotik (Torre, 2007). Dibandingkan dengan beberapa negara lain, di India pernah dilakukan penelitian pada penderita ulkus dekubitus selama 5 tahun (Juni 1997 - Mei 2002), bakteri yang paling banyak ditemukan adalah Pseudomonas aeroginosa (59\%), diikuti oleh Staphylococcus aeureus (17,9\%), Acinetobacter (7,2\%), Klebsiella spp (3,9\%), Enterobacter $(3,9 \%)$, Proteus $(3,3 \%)$, lain-lain $(4,8 \%)$. Pseudomonas aeroginosa tetap predominan dan ditemukan secara terus menerus selama 5 tahun. Pada penelitian ini pengambilan spesimen dengan cara swab pada luka. Di Indonesia, mikroorganisme pada penderita ulkus dekubitus di RSCM didapatkan Klebsiella pneumonia (23\%) sebagai mikroorganisme dominan diikuti Pseudomonas aeroginosa (20\%). Untuk Faktor kejadian pressure ulcer meliputi persepsi sensori,

kelembaban, aktifitas, mobilitas, nutrisi, serta gesekan dan robekan. Berikut pemaparan dari faktor-faktor tersebut.

Faktor persepsi dan sensori, berdasarkan hasil penelitian menunjukkan bahwa sebagian besar responden 7 (63,6\%) adalah normal/ tidak ada gangguan. Yaitu dalam berespon pada perintah verbal dengan baik, tidak ada penurunan sensorik yang akan membatasi kemampuan untuk merasakan atau mengungkapkan nyeri atau ketidaknyamanan. Persepsi sensori merupakan kemampuan untuk merespon tekanan berarti yang berhubungan dengan ketidaknyamanan. Pasien yang mengalami perubahan persepsi sensorik terhadap nyeri dan tekanan beresiko tinggi menggalami gangguan integritas kulit dari pada pasien yang sensasinya normal. Pasien yang mempunyai persepsi sensorik yang utuh terhadap nyeri dan tekanan dapat mengetahui jika salah satu bagian tubuhnya merasakan tekanan atau nyeri yang terlalu besar. (Nursalam, 2011) Sehingga ketika pasien sadar dan berorientasi, mereka dapat mengubah atau meminta bantuan untuk mengubah posisi.

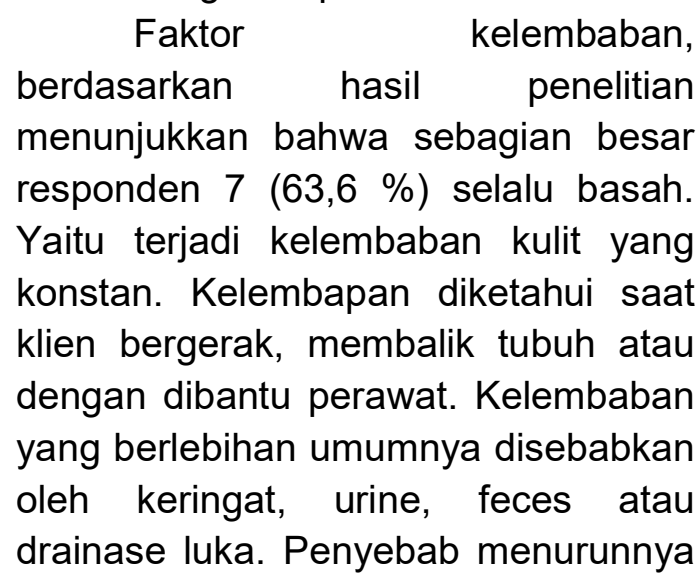


toleransi jaringan paling sering adalah kelembaban oleh urine dan feses pada pasien inkontinensia. Urine dan feses bersifat iritatif sehingga mudah menyebabkan kerusakan jaringan, jika dikombinasi dengan tekanan dan faktor lain maka kondisi kelembaban yang berlebihan mempercepat terbentuknya pressure ulcer. Kelembaban akan menurunkan resistensi kulit terhadap faktor fisik lain semisal tekanan. Kelembaban yang berasal dari drainase luka, keringat, dan atau inkontinensia feses atau urine dapat menyebabkan kerusakan kulit (Fadder, Bain, Cottendam, 2004 dalam Bryant, 2007). Secara histologis tanda-tanda kerusakan awal terbentuknya pressure ulcer terjadi di dermis antara lain berupa dilatasi kapiler dan vena serta edema dan kerusakan sel-sel endotel. Selanjutnya akan terbentuk perivaskuler infiltrat, agregat platelet yang kemudian berkembang menjadi hemoragik perivaskuler. Pada tahap awal ini, di epidermis tidak didapatkan tandatanda nekrosis oleh karena sel-sel epidermis memiliki kemampuan untuk bertahan hidup pada keadaan tanpa oksigen dalam jangka waktu yang cukup lama, namun gambaran kerusakan lebih berat justru tampak pada lapisan otot daripada pada lapisan kulit dan subkutaneus.

Faktor mobillitas dan aktifitas, berdasarkan hasil penelitian menunjukkan bahwa sebagian besar responden $7 \quad(63,6 \%) \quad$ adalah imobilisasi total dan $9(81,8 \%)$ adalah aktifitas bedrest. Mobilisasi disini, yaitu pasien tidak dapat melakukan perubahan posisi tubuh atau ekstrimitas tanpa bantuan, walaupun hanya sedikit. Sedangkan aktifitas yaitu melihat tingkat aktifitas fisik pasien, dimana pasien mengalami tirah baring atau beraktifitas terbatas di atas tempat tidur saja. Mobilisasi dan aktifitas erat kaitannya, karena bila pasien melakukan aktifitas fisik pasti memerlukan perubahan posisi tubuh dalam hal ini mobilisasi. Berdasarkan hasil penelitian sebelumnya, menunjukkan ada hubungan mobilisasi dengan kejadian dekubitus di Ruang Perawatan Intensive Care Unit Rumah Sakit Ibnu Sina Makassar $(p=0,003)$. Posisi klien immobilisasi harus diubah sesuai dengan tingkat aktivitas, kemampuan persepsi, dan rutinitas sehari-hari.Oleh karena itu standar perubahan posisi dengan interval 1 1/2 sampai 2 jam mungkin tidak dapat mencegah terjadinya dekubitus pada beberapa klien.Telah direkomendasikan penggunaan jadwal tertulis untuk mengubah dan menentukan posisi tubuh klien minimal setiap 2 jam. Saat melakukan perubahan posisi, alat bantu untuk posisi harus digunakan untuk melindungi tonjolan tulang. Untuk mencegah cidera akibat friksi, ketika mengubah posisi, lebih baik diangkat daripada diseret. Pada klien yang mampu duduk di atas kursi tidak dianjurkan duduk lebih dari 2 jam. (Hastuti, dkk., 2013)

Faktor nutrisi, berdasarkan hasil penelitian menunjukkan bahwa sebagian besar responden $6(54,5 \%)$ adalah cukup. Berdasarkan penelitian terdahulu, ada hubungan status gizi pasien dengan kejadian dekubitus di Ruang Perawatan Intensive Care Unit Rumah Sakit Ibnu Sina Makassar $(p=0,037)$. Status nutrisi buruk dapat 
diabaikan jika pasien mempunyai berat badan sama dengan atau lebih dari berat badan ideal (Hastuti, dkk., 2013). Pasien kurang nutrisi sering mengalami atrofi otot dan jaringan subkutanyang serius. Akibat perubahan ini maka jaringan yang berfungsi sebagai bantalan diantara kulit dan tulang menjadi semakin sedikit. Oleh karena itu efek tekanan meningkat pada jaringan tersebut. Malnutrisi merupakan penyebab kedua hanya pada tekanan yang berlebihan dalam etiologi, patogenesis, dekubitus yang tidak sembuh (Hanan \& scheele, 1991dalam Potter \& Perry, 2005). Pasien yang mengalami malnutrisi mengalami defisiensi protein dan keseimbangan nitrogen negatif dan tidak adekuat asupan vitamin C (Shekleton \& Litwack, 1991 dalam Potter \&Perry, 2005). Nutrisi amat penting dalam penyembuhan luka dan perkembangan pembentukan pressure ulcer. Nutrien yang dianggap berperan dalam menjaga toleransi jaringan adalah protein, vitamin A, C, E dan zinc. Bahkan Allman et al (1995), Bergstorm \& Bradden (1992), Brandeis et al (1990), Berlowitz \& Wilking (1989), Chernoff (1996) menyatakan pada fasilitas perawatan jangka panjang gangguan intake nutrisi, intake rendah protein, ketidakmampuan makan sendiri, dan penurunan berat badan berperan sebagai prediktor independen untuk terjadinya pressure ulcer. Protein berperan untuk regenerasi jaringan, sistem imunitas dan reakasi inflamasi. Kurang protein meningkatkan kecenderungan edema yang mengganggu transportasi oksigen dan nutrien lain ke jaringan. Vitamin A diketahui berperan dalam menjaga keutuhan ephitel, sintesis kolagen, dan mekanisme perlindungan infeksi. Vitamin C berperan dalam sintesis kolagen dan fungsi sistem imun sehingga kekurangan vitamin $C$ dapat mengakibatkan pembuluh darah mudah rusak (fragil). Vitamin $\mathrm{E}$ berperan dalam memperkuat imunitas sel dan menghambat radikal bebas. Melihat pentingnya peran nutrisi maka suplementasi nutrisi dianggap penting diberikan untuk pasien yang berisiko mengalami pressure ulcer. Nutrisi yang buruk khususnya kekurangan protein mengakibatkan jaringan lunak mudah sekali rusak. Nutrisi yang buruk juga berhubungan dengan keseimbangan cairan dan elektrolit (Bryant, 2007). Mechanick (2004) menyatakan kekurangan protein akan mengakibatkan edema atau sembab sehingga menggangu distribusi oksigen dan transportasi nutrien. Mathus-Vliegen (2004) menyatakan kehilangan protein yang parah hingga Hypoalbuminemia (kadar albumin serum <3 g/100 ml) menyebabkan perpindahan cairan dari ekstraseluler ke jaringan sehingga mengakibatkan edema. Edema ini akan menurunkan sirkulasi darah ke jaringan, meningkatkan akumulasi sampah merabolik sehingga meningkatkan risiko pressure ulcer (Brandon, J.W., 2012). Untuk mengkaji status nutrisi pada pasien digunakan ukuran anthropometri yaitu berat badan dan Body Mass Index (BMI), dan nilai biokimia seperti serum albumin, serum transferrin, total lymfosit, keseimbangan nitrogen, serum pre albumin serum dan serum retinol binding-protein, data klinis dan riwayat 
nutrisi (Flannigan, 1997, Strauss dan Margoliss, 1996 dalam Bryant, 2007).

Faktor gesekan dan robekan, berdasarkan hasil penelitian menunjukkan bahwa sebagian besar responden $8(72,7 \%)$ adalah memiliki masalah. Gesekan adalah kemampuan untuk menyebabkan kerusakan kulit terutama lapisan epidermis dan dermis bagian atas. Hasil dari gesekan adalah abrasi epidermis dan atau dermis. Kerusakan seperti ini lebih sering terjadi pada pasien yang istirahat baring. Pasien dengan kondisi seperti ini sebaiknya menggunakan bantuan tangan atau lengan ketika berpindah posisi utamanya kearah atas atau dibantu oleh 2 orang ketika menaikkan posisi tidurnya. Gesekan mengakibatkan cidera kulit dengan penampilan seperti abrasi. Kulit yang mengalami gesekan akan mengalami luka abrasi atau laserasi superfisial (Perry \& Potter, 2005)

DAFTAR PUSTAKA

Anders, J., Heinemann, A.,Leffmann,C., Leutenegger, M., Pröfener, F., \& von Renteln-Kruse, W. (2010). Decubitus Ulcers: Pathophysiology and Primary Prevention. Deutsches Ärzteblatt International, 107(21), 371-382. doi: 10.3238/arztebl.2010.0371

Ayello, Elizabeth A P. (2007).Predicting Pressure Ulcer Risk. Try This : Best Practice In Nursing Care to Older Adult. Issued Number 5.. Retrieved from

http://consultgerirn.org/uploads/File/t

\section{SIMPULAN DAN SARAN}

Hasil penelitian yang dilakukan pada 11 orang responden didapatkan: Jenis kuman gram negative paling banyak terdapat di pressure ulcer sebesar (81 \%) Acinetobacter sp adalah mikroorganisme yang paling dominan terdapat diluka pressure, sebanyak 63,6 \% responden memiliki persepsi dan sensori normal, sebanyak 63,6 \% kelembaban responden adalah selalu basah, sebanyak $81,8 \%$ kegiatan pasien pressure ulcer adalah bedrest, sebanyak $63,6 \%$ mobilitas responden adalah imobilisasi total, sebanyak $54,5 \%$ kondisi nutrisi responden adalah cukup, sebanyak $72,7 \%$ gesekan dan robekan reponden memiliki masalah.

Bagi para pemberi pelayanan diharapkan dapat melakukan pengkajian faktor kejadian pressure ulcer serta dapat mengendalikan infeksi pada pasien dengan ketergantungan total/ bedrest sehingga angka kejadian dapat berkurang.

rythis/issue05.pdf On March 29th, 2015.

Brandon J.W. (2012). Pressure Ulcers, Surgical Treatment and Principles.

Brown, S.J. (2004). The Braden's Scale : A Review of The Research Evidence. Retrieved from http://proquest.umi.com/pqdweb?did =1212713711. On March 29th, 2015.

Bryant, R.A. (2007). Acute and Chronic Wounds Nursing 
Management, Second Edition. Missouri, St. Louis : Mosby Inc.

Carmen, M. (2013). Risk assessment scales for pressure ulcers in intensive care and inpatient units: A systematic review with metaanalysis, 13(2), 7-13.

EPUAP, NPUAP, PPPIA. (2014). Prevention and Treatment of Pressure Ulcers: Quick Reference Guide. ISBN-10: 0-9579343-6-X, ISBN-13:978-0-9579343-6-8 $2^{\text {nd }}$ edition published. Cambridge Media on Behalf.

Era, D.K. (2009). Efektifitas skala Braden dalam memprediksi kejadian luka tekan di bangsal bedah-dalam RSU Prof. Dr. W.Z. Yohannes Kupang. Retrieved from http://www.digilib.ui.ac.id/opac/the mes/libri2/detail.jsp?id=124739. On March 29th 2015.

Gitarja, Widasari Sri. (2014). Student Handbook Perawatan Luka CWCCA. Wocare: Bogor.

Ignatavicius, D.D., \& Workman, M.L. (2006). Medical Surgical Nursing: Critical Thinking for Collaborative Care. $5^{\text {th }}$ edition. Phildelphia: W.B. Sounders Company.

Peeters, I.D. dkk. (2007). The Effectiviness of Massage With and Without Dimethyl Sulfoxida in Preventing Pressure Ulcer: A Randomized, Double-Blind CrossOver Trial in Patients Prone to Pressure Ulcers. Internastional Journal of Nursing Studies 44. 2007: 1285-1295.

Potter, P.A. \& Perry, A.G. (2005). Fundamental Of Nursing. USA : Mosby Inc.
Reddy, Madhuri., et al. Preventing Pressure Ulcer : A Systemic Review. JAMA 2008; 296(8); 974984 (doi:10.1001. Jama.296.8.974). Retrieved from http://jama.amassn.org/cgi/reprint/ 296/8/974. On March, 23, 2015.

RNAO. (2011). Risk assessment \& prevention of pressure ulcers. Nursing best practice guidline. Revised 2011 supplement enclosed.

Scheel-Sailer, A., Wyss, A., Boldt, C., Post, M., \& Lay, V. (2013). Prevalence, location, grade of pressure ulcers and association with specific patient characteristics in adult spinal cord injury patients during the hospital stay: a prospective cohort study. Spinal cord, 51(11), 828-833.

Spilsbury, K., et al. Pressure Ulcers and Their Treatment And effects On Quality Of Life : Hospital Inpatient Perspectives. Journal of advanced nursing volume 57. 2010: number; 5 page 494-504. Retrieved from http://www.ebscohost.com/uph.ed u on March 23, 2015.

Suriadi, Sanada H, Junko S, Thigpen B,Subuh M. (2008). Development of a new risk assessment scale for predicting pressure ulcers in an intensive care unit. Journal British Association of Critical Care Nurse, Nursing in Critical Care (13):34-43

Walburga B. Maria. Perbandingan efektifitas skala braden dan norton dalam memprediksi risiko dekubitus di ruang ICU RSUD Tugu Rejo Semarang. Tesis Universitas Diponegoro Semarang. 2014. 
Widodo, A. (2007). Uji kepekaan instrumen pengkajian risiko dekubitus dalam mendeteksi dini risiko kejadian dekubitus di RSIS. Jurnal penelitian sains dan teknologi. 54: 40

Wound Care Solutions Telemedicine. Wounds. [Online]. 2010 [citez 2010 april 3], Availabel from; URL http://www. woundcaresolutions-

telemedicine.co.uk/wounddefinition .php).

Yasa, I.D.P.G.P. Analisis Praktek Residensi Keperawatan Medikal Bedah Pada Kasus Sistem Neurologi Di RSUPN Dr. Cipto Mangunkusumo Jakarta. Jakarta: FIK-UI. 2010. Laporan tidak dipublikasikan.

Zakiyyah, Syifa. Pengaruh mobilisasi progresif level 1 terhadap risiko dekubitus dan perubahan saturasi oksigen pada pasien kritis terpasang ventilator di ruang ICU RSUD Moewardi Surakarta. Tesis Universitas

Diponegoro

Semarang. 2014. 